\title{
Assessing the adoption of household safety protection (HSP) in Stockholm, Sweden
}

\author{
Bridget da Costa* and Vania Ceccato
}

\begin{abstract}
This study examines the adoption of household safety protection (HSP) measures in Stockholm, the capital of Sweden. Drawing upon assumptions from environmental criminology and situational crime prevention, the study explores the impact of crime and fear of crime on HSP. Geographical Information System (GIS) combines in a single dataset data on HSP adoption: a cross-sectional resident safety survey, socio-demographic statistics of the areas and newspaper vignettes. A pre-analysis of the data is used to check whether HSP adoption varied by tenancy type. Then, hypothesis testing is performed using binary logistic regression models to identify significant predictors of HSP, including individuals' previous victimization, perception of high crime rates in the neighborhood, declared altruistic fear, and exposure to crime in the local media, while controlling for individual and areal covariates. Protection strategies are found to differ significantly according to tenancy type, and among those who rent, HSP varies by type of housing company. The likelihood of having several types of HSP was found to increase with perception of crime and altruistic fear but to only a small extent, previous victimization.
\end{abstract}

Keywords: Alarms; Crime; Altruistic fear; Situational crime prevention; Binary logistic regression; GIS

\section{Introduction}

The adoption of household safety protection (HSP) may be a behavioral response to crime, particularly residential burglary (Greenberg 1987). Victims of burglary suffer not only the loss of property, but often struggle with a sense of violation and lasting experience of fearfulness (Maguire and Bennet 1982). Locks and burglar alarms are examples of devices used to prevent/discourage the crime of burglary, but the range of HSP services and products is diverse and ever expanding. Cameras, guard booths, perimeter security and even paper shredders are security products aimed to protect the owner's person, property, identity and other sensitive information. Whereas burglary is a relatively rare crime in Sweden, experienced by only $1 \%$ of Sweden's residents in any given year, fear of having their home burgled is reported by $16 \%$ (The Swedish National Council for Crime Prevention (Brå) 2008) and many Swedes report using some sort of HSP to protect their home (Roth and

\footnotetext{
* Correspondence: bridget.dacosta@abe.kth.se

Housing and Safety Research Group Department of Urban Planning and Environment School of Architecture and the Built Environment (ABE) Royal Institute of Technology (KTH), Drottning Kristinasväg 30, 10044 Stockholm, Sweden
}

Sandahl 2008). For this reason the process of adoption of HSP remains an important area of study.

The number and types of HSP present in a home may depend on many factors beyond the fear of burglary. Previous research has linked the consumption of HSP to the demographic and socio-economic profile of the residents or of the area where they live (Nilsson and Estrada 2006), fear of crime (Warr and Ellison 2000), requirements of insurance companies (Loader 1999; Zedner 2006) and even the exposure to security gadgets through media and marketing (Goold et al. 2010). Perhaps due to key oversights, the existing research provides few definitive explanations of HSP adoption. Shortcomings include the neglect of the impact of tenancy arrangements on HSP and the prevalence of North American and British study areas. As such, it is unclear whether current evidence of HSP adoption can be generalized to other countries and types of cities. This study makes a contribution to the existing knowledge base by addressing HSP adoption in a Swedish context.

The objective of the article is two-fold. First, the influence of tenancy type on the consumption of security measures is considered. Second, the study examines the assumed link between crime and fear of crime on HSP

\section{Springer}


adoption. Various dimensions of safety are addressed, such as previous victimization and fear of crime and awareness of crime in the surrounding neighborhood, while controlling for household and area characteristics.

The capital of Sweden constitutes an interesting case study due to its mixed ownership types, welfare state and rising crime levels. Housing in Stockholm municipality is characterized by predominantly multi-dwelling buildings and some districts with single-family homes. Whereas previous research on HSP adoption has been limited to the decision-making of single-family homeowners, Stockholm's multi-family buildings represent a mix of ownership and tenure-types, including public and privately managed rental units and cooperatively owned condominium associations. Furthermore, a welfare society such as Sweden may also reflect different consumer attitudes and/or barriers to the adoption of HSP that are not found in more market oriented societies, such as in the United States or Great Britain. Finally, home security may be of increasing concern to Swedes, and particularly to residents of the urban centers (Svenska Dagbladet 2013) due to increased incidence of burglary. The rate of burglary in Europe has been rising on average in recent years, but Sweden (along with Denmark, Greece and Romania) led the EU with a rise of over $20 \%$ over the period 2006-2009 (Eurostat 2012).

\section{Background}

This study investigates HSP in Stockholm, the capital city of Sweden. The municipality of Stockholm has a population of about 850,000 , and the metropolitan area numbers over 2 million (USKAB 2010). It is important to first note that Sweden relatively a safe country with regards to burglary. Victimization rates for burglary in Sweden were the lowest of all EU nations surveyed in a 2004 study by UNICRI (Van Dijk et al. 2005). Still, large metropolitan regions tend to experience disproportionately high rates of burglary, and Sweden is no exception. According to 2008 police statistics, Stockholm County has the third highest residential burglary rate in Sweden (after Skåne and Halland counties). In 2008, Stockholm registered a rate of 5 burglaries per 1000 inhabitants, 2.5 times the rate of burglary in the country as a whole $(1.9$ per 1000) (Brå - the Swedish National Council for Crime Prevention 2008). Burglaries are unevenly distributed among Stockholm municipality district areas. Burglaries range from a low rate of around 3 per 1000 residents in the inner city to a high of over 7 per 1000 residents in the outlying areas.

Housing in Stockholm municipality is characterized by a mixture of multi-dwelling buildings and single-family homes each representing a mix of ownership and tenure-types. These include rental, in which the occupant holds a term lease for the property; condominium or bostadsrätt, in which the occupant owns the right to occupy an apartment; and owner-occupation, in which the owner of the unit is also the occupant. The most common dwelling type is condominiums ( $45 \%$ of housing units), followed by rental units $(37 \%)$. The least common form of housing is the owner-occupied singlefamily or row-house (16\% of dwelling units). Condominiums and rental units in Stockholm municipality are usually located in multi-family and higher density buildings that dominate the inner city areas and some outer districts. The majority of single-family homes are located in a few of the outer districts of the municipality. In Stockholm municipality, building type and type of tenancy are not necessarily related to financial status. While some outer districts of predominately single-family homes have high average incomes, so do many of the inner city districts, which consist almost exclusively of multi-family rental and condominium buildings.

Although household burglary rate is quite consistent across tenancy types in burglaries are not equally reported among all tenancy types. It is estimated that while $86 \%$ of burglaries in villas are reported to the police, only $67 \%$ of burglaries in multi-dwelling buildings are reported. Furthermore, the growth in burglaries is not distributed evenly among tenancy types: there has been a trend towards an increased proportion of burglaries in multi-dwelling buildings. According to a report by Brå, burglaries in multi-dwelling buildings increased from $33 \%$ of the total in 2003 to $43 \%$ in 2007 (Töyrä 2008). For all of these reasons, it is important to look more closely at the link between tenancy type and HSP purchases.

Beyond the question of tenancy type, there is a rich literature on the triggers and/or conditioning factors for the adoption of HSP. Since household safety protection measures (HSP) are thought to be a behavioral response to crime, it may be assumed that variations in crime and safety such as previous victimization, crime in the surrounding neighborhood and fear of burglary would impact its adoption at household level.

Previous victims of crime may be more likely to adopt increased home security (Lavrakas and Lewis 1980). However, two recent US studies in this topic came to opposite conclusions. May et al. (2010) found that previous victims of property crime (especially women) adopted more security measures than those who had not been victimized, but Averdijk (2010) did not. The difference between the findings of the two studies could be attributed to the way that each study calculated the presence of security measures May et al. (2010) used a binary measure (has security measures or does not have security measures), whereas Averdijk (2010) calculated an index based on the number of different security measures reported. 
It has also been suggested that an awareness of crime in the neighborhood (including awareness of incivilities or social disorder) may be a driving force of HSP adoption but, again, evidence is mixed. In a study of residents of a high-density urban community in the UK, Hirschfield et al. (2004) found that perceptions of a crime problem led to increased security purchases, whereas the previously cited US study (May et al. 2010) found no significant relationship between awareness of crime and the adoption of HSP.

Researchers have often assumed that adoption of HSP would increase with fear levels (e.g., Smith and Pain 2009; Lauer 2005; Rodgers 2004). Fear of crime is defined as a negative emotional reaction to crime including that of physical harm, material loss, shame or humiliation. North American studies by Rountree and Land (1996) and Ferguson and Mindel (2007), found that selfreported fear of burglary was associated with increased household protection. However, fear of crime is multifaceted phenomenon and is made up of a number of components (Gabriel and Greve 2003). Warr and Ellison (2000) suggest that "personal fear" is fear for the self, whereas "altruistic fear" is fear for the safety of a loved one, such as a child, spouse, lover, friend or relative. While personal fear has been found to be a good predictor of avoidance behaviors, such as not going out alone or not going out at night, altruistic fear has been linked to the adoption of HSP (Warr and Ellison, 2000). This study's respondents were more likely to add HSP in response to fear for loved ones than out of fear for themselves, indicating that fear of crime is at least partly a social phenomenon.

Consumers of HSP may also be influenced by exposure to crime in the media. Television, online and print media often highlights tragic stories of victims as well as dramatized representations of offenders. This may cause readers to identify strongly with the plight of the victim, elevate fear levels, and encourage a more defensive stance towards crime (Demker et al. 2008). Despite the possible importance of this link, little is found in the international literature linking crime in the media and HSP adoption. One aim of our study is to take an empirical look at this relationship.

Insurance companies may encourage people to acquire HSP (Loader 1999; Zedner 2007). Specific insurance policies may encourage different HSP purchases, depending on the type of home that is being insured and perhaps the crime profile of the surrounding area. In Stockholm, over $95 \%$ of residents of both single-family homes and multi-family buildings buy home and belonging insurance (Roth \& Sandahl 2008), so it would be expected that any differences in insurance policy terms may impact on the homeowner or renter's HSP decision-making. Residential stability may also affect HSP adoption, as a greater number of years spent in one's accommodation may be associated with more home improvements, including HSP.

Beyond crime and safety, a number of other individual and neighborhood factors are thought to impact the adoption of HSP, based upon theories such as rational choice, routine activity and situational crime prevention (see e.g. Clarke, 1995). For instance, since attractive (i.e., more valuable) targets are more vulnerable to burglary, people owning many valuable belongings are expected to take steps to protect these. A number of previous studies have shown an association between high income and higher levels of HSP (Lee 2010b; Tilley et al. 2011; Nilsson and Estrada 2006). Routine activities theory posits that a crime happens in the convergence in time and space of a likely offender and a suitable target in the absence of a capable guardian (Cohen and Felson 1979). Women and the elderly report being more fearful of becoming targets of crime (Warr 1984), whereas males tend towards altruistic fear (Warr and Ellison 2000). Therefore, gender and advanced age may be relevant factors for the adoption of security measures. Lee et al. (2008) found that elderly residents adopt HSP differently than the general population.

Finally, building and tenancy type may impact on HSP adoption. For instance, single-family houses and multistory, multi-family dwellings suffer different types of break-ins as the result of differing physical configurations, and due to this, HSP adoption may differ. In Sweden, the most common means of illicit entry of single-family villa homes is through a window (38\%), followed by a deck or balcony door (27\%), and least commonly, an entry door (20\%). On the other hand, burglars enter apartments located in multi-dwelling buildings most often through the entry door (46\%), followed by windows (26\%), and finally a balcony door (18 \%) (Töyrä 2008). Responsibility for the purchase of HSP also varies according to tenancy type: whereas the owners of single-family houses purchase their own HSP, and the members of condominium associations may purchase some HSP within a collective security improvement project, renters may rarely purchase their own HSP. Surprisingly, very few studies in the international literature have considered how the adoption of HSP varies with building or tenancy type. One Australian study of elderly residents found that renters were less likely to install burglar alarms (Lee 2010a). Lee et al. (2008) also showed that renters installed fewer protections of all types. Gelders et al. (2007) found that it was not the renters but the property owners and management companies that tended to make decisions with regard to HSP. Since Sweden does not have a national standard for household protections, it can be assumed that HSP would vary by building and tenancy type, and that the 
presence of HSP in rental properties can be attributed to Stockholm's municipal and private housing companies, not the renters themselves.

To summarize, in Stockholm municipality, it is hypothesized that the adoption of HSP will vary according to:

\section{- tenancy type}

Also, it is hypothesized that the adoption of HSP increases as does:

- previous victimization,

- awareness of crime in the surrounding neighborhood,

- self-reported altruistic fear, and

- fear of crime as portrayed by the local media.

\section{Methods}

The data for this study came from three sources. The main source was the 2008 Stockholm safety survey conducted by USK, Stockholm City Investigation and Statistics AB. A block random sample of 250 inhabitants 18 years and older were selected within each of 132 parishes in the Stockholm Municipality. The survey achieved an overall response rate of $63 \%$ yielding a total of 20,515 cases. Socio-economic data from 2008 was obtained from the Swedish Area Database $(O D B)$ collected by the SCB, the central authority for collecting statistics in Sweden. Finally, an online information search targeted the phrase "fear of crime" in a widely distributed and free local newspaper archive (Mitt $i$ ) for the years 2006-2012. Versions of Mitt $i$ are printed weekly and distributed free of charge to approximately $60 \%$ of all residential addresses in Stockholm municipality (Mitt i 2014). The paper's content varies in each of twelve distribution zones in Stockholm municipality. Articles about fear of crime were sorted by zone of publication, and an index of exposure, based upon the frequency of articles reporting crimes, was created.

\section{Pre-analysis}

Preparation of the data included testing for representativeness, correlation analysis, principal component analysis (PCA) and cross-tabulation analyses, see Table 1. Three parishes (Lunda, Farstanäset and Flaten) were outliers with extremely small populations $(\mathrm{n}<10)$, and therefore removed from the dataset. Demographic indicators of safety survey respondents (gender, over 65 years of age, and of non-Swedish origin) were compared with official USK statistics at the parish level, which showed the survey population to be sufficiently representative of Stockholm Municipality as a whole.
Survey respondents were asked which of eight HSP items they used to protect their home (See Appendix). Three were discarded from the analysis because they were difficult to interpret (i.e., does a respondent who does not indicate a lock on balcony door have a balcony door with no lock, or do they live in an apartment with no balcony?). A principal component analysis (PCA) of the five remaining HSP items (burglar alarm, safety deposit box, safety locks, security door, watch dog) produced no internally consistent components, which is interpreted as evidence that each item follows a distinct pattern of adoption. These five variables were used as unique dependent variables for all of the following analysis.

Fourteen survey questions were selected as independent variables. The PCA identified one meaningful component: a constellation of variables which appear to represent either financial comfort or good financial planning. It included four variables: (1) I/we go on vacation trips every or every other year, (2) I/we can go to the dentist when we need to and at least once a year, (3) if, because of unforeseen circumstances, I/we should need 14000 Swedish crowns within a week, is it possible for me/us to raise this, and (4) I/we regularly save money for my/our retirement. These were summed into an index, "financial umbrella". It is moderately internally consistent with a Cronbach's alpha $(\alpha)=.68$.

\section{Measuring the impact of safety on HSP adoption}

After these steps all independent and dependent variables were combined into a single GIS database based upon the 132 parishes of Stockholm municipality (Table 2 shows a description of the dataset).

Crosstabulation and tests of independence were used to describe the adoption of HSP according to tenancy. Pearson's chi-square test of independence determines whether the relationship between two categorical variables is statistically significant. However, the chi-square coefficient $\left(\chi^{2}\right)$ may be difficult to interpret. The $\chi^{2}$ may appear large and significant simply due to a large sample size. Other measures of association can be helpful in determining the meaning of the statistically significant association. Cramer's V can be used to compare several $\chi 2$ measures since it may be generalized across contingency tables of varying sizes and it is not affected by sample size. It is interpreted as a measure of the relative strength of the association between two variables. It ranges in value from 0 to 1 . A commonly used rule-ofthumb considers an association of $\mathrm{V}>.10$ to indicate a substantive relationship between two variables (AcaStat 2012). We used Cramer's V to measure the importance of the relationship between the HSP measures and tenancy type. 
Table 1 Measures of association between HSP and tenancy type

\begin{tabular}{|c|c|c|c|c|c|c|}
\hline $\mathrm{HSP}$ & Rental $^{a}(\%)$ & Condominium ${ }^{\mathrm{b}}(\%)$ & Row-house/ villa ${ }^{c}(\%)$ & Pearson's chi-square $\left(x^{2}\right)$ & Cramer's V & Sig. \\
\hline Burglar alarm & $198(2.5)$ & $256(4.0)$ & $2997(53.1)$ & 7073.990 & .595 & .000 \\
\hline Lock on balcony door & $835(10.4)$ & $997(15.7)$ & $2939(52.0)$ & 3493.068 & .418 & .000 \\
\hline Locks on some windows & $456(5.7)$ & $497(7.8)$ & $2302(40.8)$ & 3473.300 & .417 & .000 \\
\hline Security door & $2404(30.0)$ & $2471(38.9)$ & $212(3.8)$ & 2094.151 & .324 & .000 \\
\hline Safe deposit box & $795(9.9)$ & $1004(15.8)$ & $1701(30.1)$ & 952.178 & .218 & .000 \\
\hline Watch dog & $389(4.9)$ & $272(4.3)$ & $548(9.7)$ & 187.667 & .097 & .000 \\
\hline Wrought-iron gate & $286(3.6)$ & $382(6.0)$ & $163(2.9)$ & 84.577 & .065 & .000 \\
\hline Safety locks & 3048 (38.0) & 2731 (43.0) & $2333(41.3)$ & 37.524 & .043 & .000 \\
\hline
\end{tabular}

${ }^{a} n=8035$; approximately $97.5 \%$ responding

${ }^{\mathrm{b}} n=6367$; approximately $97.5 \%$ responding

$c_{n}=5652$; approximately $97.5 \%$ responding

The data was sorted into three subgroups by tenancy type. Binary logistic regression was selected to model the hypotheses. The model results were interpreted using the the exponentiated value of the parameters of each independent variable. $\operatorname{Exp}\left(\beta_{i}\right)$ is the multiplicative effect on the odds of a 1-unit increase in $x_{i}$, at fixed levels of the other $x$ s (Agresti 2007, 115). A model was estimated for each of the five types of HSP, within each of the three tenancy type subgroups, totaling 15 models. Five models indicating unbalanced data, as per
Agresti (2007, 138) were omitted (security door in villa, safety deposit box and burglar alarm in rental and condominium).

In order to identify any effect of rental ownership on the adoption of HSP, two additional models were estimated, using the independent variables used in the first set of models, plus a categorical variable called "ownership". Security doors and safety locks were used as the dependent variables, since an entry door is the most common access point for burglars of rental units (Töyrä 2008).

Table 2 The database of the study

\begin{tabular}{|c|c|c|c|c|c|c|c|}
\hline & Variable & Survey item & Level of measurement & Range & Mean & SD & Source \\
\hline \multirow[t]{10}{*}{ Independent } & Burglary victim & $\begin{array}{l}\text { During the past } 12 \text { months has your } \\
\text { home been exposed to a robbery } \\
\text { or theft? }\end{array}$ & Binary & $0-1$ & .17 & .379 & Survey \\
\hline & Perception of crime & $\begin{array}{l}\text { Have you heard of any crime, such as } \\
\text { burglary, car-related or vandalism, that } \\
\text { has been committed in your } \\
\text { neighborhood? }\end{array}$ & Ordinal & $0-3$ & 2.31 & .854 & Survey \\
\hline & Altruistic fear & $\begin{array}{l}\text { Have you worried that someone close } \\
\text { to you has been affected by crime? }\end{array}$ & Ordinal & $0-3$ & .82 & .826 & Survey \\
\hline & Fear in media & NA & Ordinal & $0-4$ & 1.88 & 1.244 & Mitt i \\
\hline & Financial umbrella & Summative index of five survey items & Ordinal & $0-4$ & 2.73 & 1.27 & Survey \\
\hline & Trouble paying bills & $\begin{array}{l}\text { It has happened a few times during } \\
\text { the past } 12 \text { months that I / we have } \\
\text { had difficulty paying bills. }\end{array}$ & Binary & $0-1$ & .10 & .300 & Survey \\
\hline & Unemployed (\% in district area) & NA & Interval & $.00-3.65$ & 1.41 & .757 & ODB \\
\hline & Residential stability & $\begin{array}{l}\text { How long have you lived in your present } \\
\text { neighborhood? }\end{array}$ & Ordinal & $0-2$ & 1.53 & 651 & Survey \\
\hline & Tenancy & What type of housing do you live in? & Categorical & $0-2$ & NA & NA & Survey \\
\hline & Rental Ownership & $\begin{array}{l}\text { Is your rental apartment owned by } \\
\text { Svenskabostäder, Familjebostäder, } \\
\text { Stockholmshem or a private owner? }\end{array}$ & Categorical & $0-3$ & NA & NA & Survey \\
\hline \multirow[t]{5}{*}{ Dependent } & HSP & Burglar alarm & Binary & $0-1$ & .17 & .375 & Survey \\
\hline & & Safe deposit box & Binary & $0-1$ & .17 & .378 & Survey \\
\hline & & Safety locks & Binary & $0-1$ & .40 & .490 & Survey \\
\hline & & Security door & Binary & $0-1$ & .25 & .434 & Survey \\
\hline & & Watch dog & Binary & $0-1$ & .06 & .237 & Survey \\
\hline
\end{tabular}




\section{Results}

\section{HSP and type of tenancy}

Type of tenancy was hypothesized to be a determinant of HSP adoption in Stockholm, and the results of this study show strong support for this idea. 'Burglar alarm,' 'locks on balcony door,' 'locks on some windows,' 'security door', and 'safe deposit box' were all shown to be highly associated with tenancy type $(\mathrm{V}>.10$, Table 1$)$. For example, neither rental dwellers nor condominium owners are very likely to have a burglar alarm, whereas respondents living in row-houses or villas report them more than half of the time. With regard to security door, both renters and condominium dwellers report security doors five times more frequently as do villa owners. 'Safety locks', 'watch dog' and 'safe deposit box' were not strongly associated with tenancy type $(\mathrm{V}<.10)$.

\section{The impact of safety on HSP adoption}

Several aspects of crime awareness and fear of crime were hypothesized to be determinants of HSP adoption in Stockholm. This study found that HSP in Stockholm does vary significantly with residents' perception of a crime problem and altruistic fear. Those who were aware of many crimes in the neighborhood were more likely to report the adoption of almost all types of HSP. Interestingly, high awareness of crime in the neighborhood was associated with the presence of watch dogs for both renters and condominium dwellers. A one-unit increase in perception of a crime problem was associated with a $43 \%$ increase in the odds of having a watch dog for renters and a $29 \%$ increase in the odds of having a watch $\operatorname{dog}$ for condominium dwellers. On the other hand, owners of villas/row-houses reporting high awareness of crime were not more likely to possess a watch dog. The significance of having a watch dog must be interpreted with caution, though, since people keep dogs for many different reasons, and security may be just one of them.

Altruistic fear is significantly associated with increased adoption of HSP among all tenancy types and the effect sizes are moderate $(10-30 \%$ increase in the odds of adoption). This finding is an affirmation of previous research pointing to the influence of altruistic fear on HSP (Warr and Ellison 2000).

On the other hand, having experienced a burglary during the last year was not associated with the adoption of most types of HSP (Table 3). Exceptions were burgled renters who reported more safety locks; burgled condominium dwellers who reported more security doors; and previously victimized villa owners who reported more watch dogs.

The "fear in the media" index was significantly associated with increased adoption of HSP in only four of the models; and the strength of the effect of the variable is small $(0.85<\operatorname{Exp}(\beta)<1.11)$. These findings give only limited support to the hypothesis that fear of crime as portrayed in the media increases the adoption of HSP. Possible explanations for the weakness of this variable are discussed in the following section.

A number of control variables were included in the models to account for known correlates of HSP adoption. These control variables performed mostly as expected. High socio-economic status or good financial planning, "financial umbrella", was linked to the adoption of most types of HSP. These results confirm previous findings, (e.g., Tilley et al. 2011; Nilsson and Estrada 2006), but also expand upon previous literature by demonstrating that the adoption of some types of HSP increase with socioeconomic status in all tenancy forms. Also in line with expectations, those who reported having trouble paying monthly bills are somewhat less likely to adopt some forms of HSP. The power of the effect of these two individual measures of socio-economic status appears to be similar for all tenancy types, but not for all types of HSP.

Area unemployment is associated with a decrease in the likelihood of some HSP for villa owners, as expected, but it was linked to an increase of some protection measures for renters and condominium dwellers. The variable had the greatest effect on security doors for renters, with a one percent increase in unemployment rate in the parish being associated with a $34 \%$ increase in the odds of having a security door.

Residing in the neighborhood for a longer period of time prior to the survey was associated with increased probability of some types of HSP. This effect appeared to be most important for the villa and row-house owners. For this tenancy type, a one-unit increase in the residential stability variable was associated with a $19 \%$ increase in the odds of having safety locks, a $37 \%$ increase in the odds of having a watch dog, and an $89 \%$ increase in the odds of having a safe deposit box. This finding suggests that time is required to develop HSP strategies: additional years in the residence allow more time for completing home improvements, including the purchase and installation of HSP.

Regarding individual characteristics and HSP adoption, findings show that elderly respondents were consistently more likely to report almost all types of HSP in all tenancy categories. The power of this variable across the board was remarkable, with elderly renters reporting safety locks with $101 \%$ greater odds (along with $115 \%$ greater odds for elderly condominium dwellers, and $63 \%$ for elderly villa and row-house dwellers) as compared to those less than 65 years of age. They are also significantly more likely to report security doors in condos and safety deposit boxes. Exceptions are watch dogs and burglar alarms, which were reported less frequently by elderly respondents. 
Table $\mathbf{3}$ Logistic regression of HSP by tenancy

\begin{tabular}{|c|c|c|c|c|c|c|c|c|c|c|c|}
\hline & & \multicolumn{3}{|l|}{ Rent } & \multicolumn{3}{|l|}{ Condo } & \multicolumn{4}{|l|}{ Villa/Row-house } \\
\hline & & Door & Locks & Dog & Door & Locks & Dog & Locks & Dog & Alarm & Box \\
\hline \multirow[t]{8}{*}{ Safety } & Perception of crime ${ }^{b}$ & $0,131^{* *}(1,141)$ & $0,099^{* *}(1,104)$ & $0,357^{* *}(1,429)$ & $0,089 * *(1,093)$ & $0,133^{* *}(1,142)$ & $0,256^{* *}(1,291)$ & $0,118^{* *}(1,125)$ & $0,105(1,111)$ & $0,150^{* *}(1,162)$ & $0,166^{* *}(1,181)$ \\
\hline & Burglary victim & $0,038(1,039)$ & $0,167^{*}(1,181)$ & $0,106(1,112)$ & $-0,175^{*}(, 840)$ & $-0,128(, 880)$ & $-0,085(, 919)$ & $-0,014(, 986)$ & $0,268^{*}(1,308)$ & $0,005(1,005)$ & $-0,064(, 938)$ \\
\hline & Fear in the media & $0,098^{* *}(1,103)$ & $0,021(1,021)$ & $-0,008(, 992)$ & $0,063^{* *}(1,065)$ & $0,004(1,005)$ & $-0,013(, 987)$ & $0,052^{* *}(1,053)$ & $-0,016(, 984)$ & $0,005(1,005)$ & $-0,052^{*}(, 95)$ \\
\hline & Residential stability & $0,020(1,02)$ & $0,324^{* *}(1,383)$ & $0,166(1,18)$ & $-0,03(, 970)$ & $0,179 * *(1,196)$ & $-0,172(, 842)$ & $0,177^{* *}(1,193)$ & $0,315^{* *}(1,370)$ & $-0,081(, 922)$ & $0,634^{* *}(1,885)$ \\
\hline & Financial umbrella & $0,102^{* *}(1,107)$ & $0,114^{*}(1,120)$ & $-0,105(, 901)$ & $0,114^{* *}(1,12)$ & $0,127^{* *}(1,135)$ & $-0,058(, 943)$ & $0,071^{*}(1,074)$ & $-0,131^{*}(, 877)$ & $0,239 * *(1,269)$ & $0,086^{*}(1,090)$ \\
\hline & Trouble paying bills & $-0,251^{* *}(, 778)$ & $-0,027(, 973)$ & $0,261(1,298)$ & $-0,199(, 820)$ & $-0,289 *(, 749)$ & $0,369(1,446)$ & $-0,084(, 920)$ & $0,266(1,304)$ & $-0,322^{*}(, 725)$ & $-0,332^{*}(, 718)$ \\
\hline & Altruistic fear & $0,169 * *(1,184)$ & $0,129 * *(1,137)$ & $0,206^{* *}(1,228)$ & $0,046(1,047)$ & $0,167^{* *}(1,182)$ & $0,179 *(1,196)$ & $0,204^{* *}(1,227)$ & $0,188^{* *}(1,207)$ & $0,174^{* *}(1,19)$ & $0,242^{* *}(1,274)$ \\
\hline & Unemployed (area \%) & $0,292^{* *}(1,339)$ & $0,151^{* *}(1,163)$ & $-0,029(, 971)$ & $0,144^{* *}(1,155)$ & $-0,032(, 968)$ & $-0,061(, 941)$ & $0,010(1,010)$ & $-0,139(, 871)$ & $-0,207^{* *}(, 813)$ & $-0,140^{* *}(, 869)$ \\
\hline \multirow[t]{10}{*}{ Control } & Gender ( 1 = male) & $-0,057(, 945)$ & $0,063(1,065)$ & $-0,153(, 858)$ & $0,054(1,056)$ & $-0,016(, 984)$ & $-0,208(, 812)$ & $0,397 * *(1,487)$ & $-0,082(, 921)$ & $0,063(1,065)$ & $0,048(1,05)$ \\
\hline & Elderly ( 1 = over 65 ) & $0,012(1,012)$ & $0,700^{* *}(2,014)$ & $-0,533^{* *}(, 587)$ & $0,547^{* *}(1,729)$ & $0,765^{* *}(2,148)$ & $-0,092(, 912)$ & $0,489^{* *}(1,630)$ & $-0,191(826)$ & $-0,106(, 899)$ & $0,926^{* *}(2,525)$ \\
\hline & Constant & $-2,463^{* *}(, 085)$ & $-2,068^{*}(, 126)$ & $-3,881(, 021)$ & $-1,466^{*}(, 231)$ & $-1,333^{* *}(, 264)$ & $-3,266^{* *}(, 038)$ & $-1,884(, 152)$ & $-2,683^{* *}(, 068)$ & $-0,616^{* *}(, 540)$ & $-2,56^{*}(, 077)$ \\
\hline & Chi-square (df) & $321.1(10)^{* *}$ & $327.8(10)^{* *}$ & $89.6(10)^{* *}$ & $123.7(10)^{* *}$ & $219.6(10)^{* *}$ & $26.9(10)^{*}$ & $161.3(10)^{* *}$ & $50.3(10)^{* *}$ & $155.9(10)^{* *}$ & $344.2(10)^{* *}$ \\
\hline & -2log likelihood & 8776.621 & 9499.118 & 2833.069 & 7932.545 & $8,006.5$ & 2109.243 & 7092.15 & 3357.167 & 7234.872 & 6202.130 \\
\hline & Nagelkerke $\mathrm{R}^{2}$ & 0.06 & 0.059 & 0.037 & 0.028 & 0.048 & 0.015 & 0.04 & 0.02 & 0.038 & 0.088 \\
\hline & Model \% correct & 69.7 & 63.2 & 95 & 61.5 & 60 & 95.7 & 60.5 & 90.3 & 57.3 & 70.5 \\
\hline & Null \% correct & 69.6 & 62.1 & 95 & 60.9 & 57 & 97.7 & 58.7 & 90.3 & 53.5 & 69.9 \\
\hline & Improvement from null & 0.1 & 1.1 & 0 & 0.6 & 3 & -2 & 1.8 & 0 & 3.8 & 0.6 \\
\hline & $N$ & 7407 & 7406 & 7406 & 6019 & 6019 & 6019 & 5350 & 5350 & 5350 & 5350 \\
\hline
\end{tabular}

Due to small number of observations, regressions for burglar alarm, safety deposit box, and safety door were only run in certain tenancy categories

${ }^{*}$ significant at $p<.05$

**significant at $p<.01$ 
It has also been suggested that gender may affect HSP adoption but in the Stockholm case, this was quite minimal, with only one significant result. Male residents of villas or row-houses showed a $49 \%$ increase in the odds of reporting safety locks than female residents of villas.

Finally, it was hypothesized that the adoption of HSP could vary across housing companies. To examine the effect of building ownership, two models were estimated for security door and safety locks in rental properties. In addition to the independent variables included in the main models (Table 3), a categorical variable for rental ownership was added. The results show that type of building ownership significantly increased the odds of security door adoption over the default variable, which was private ownership (Table 4). This means that privately owned apartment units are less likely to have security doors as compared to publically owned rental apartment units. The addition of the ownership dummy variable in the expanded model resulted in a significant 136.62 Chi-Square improvement in the model for security doors; an improvement of the Nagelkerke pseudo R2 from .060 to .085 ; and a prediction improvement from the null of $.4 \%$. All three housing companies were significantly more likely to have installed security doors as compared to privately owned apartments (104 \% increased odds for Svenska bostader respondents, $97 \%$ for Familie bostader, and 67 \% for Stockholmshem). On the other hand, type of owner was not significantly associated with a change in the odds of installing safety locks.

\section{Discussion}

One aim of the study was to determine the influence of tenancy type on the consumption of security measures. The findings indicate that tenancy type does indeed have a significant impact - homeowners, condominium owners and renters adopt different types of security measures at significantly different rates. The most important difference is between single-family dwellings and multi-family buildings, regardless of whether the multi-family dwellings are member owned (condominiums) or rented. Table 1 reveals that, with regards to HSP profile, condominium dwellers are best grouped along with rental dwellers. In other words, although Stockholm's condominium housing is more similar to row-houses/villas with regard to ownership status, in terms of both its' physical form and HSP adoption it is most similar to rental housing. This finding

Table 4 Multi-level logistic regression with dummy for apartment owner

\begin{tabular}{|c|c|c|c|c|c|}
\hline \multirow[b]{2}{*}{ Safety } & \multirow[b]{2}{*}{ Burglary victim } & \multicolumn{2}{|c|}{ Renters with security doors } & \multicolumn{2}{|c|}{ Renters with safety locks } \\
\hline & & $0,038(1,039)$ & $0,024(1,153)$ & $0,167^{*}(1,181)$ &, $165^{*}(1,179)$ \\
\hline & Perception of crime & $0,131^{* *}(1,141)$ & $0,142^{* *}(1,153)$ & $0,099 * *(1,104)$ &, $099^{* *}(1,104)$ \\
\hline & Altruistic fear & $0,169^{* *}(1,184)$ & $0,173^{* *}(1,189)$ & $0,129^{* *}(1,137)$ &, $129^{* *}(1,138)$ \\
\hline & Fear in the media & $0,098^{* *}(1,103)$ & $0,081^{* *}(1,085)$ & $0,021(1,021)$ &, $018(1,018)$ \\
\hline & Financial umbrella & $0,102^{* *}(1,107)$ & $0,130^{* *}(1,139)$ & $0,114^{*}(1,120)$ &, $115^{* *}(1,122)$ \\
\hline \multirow[t]{5}{*}{ Control } & Trouble paying bills & $-0,251^{* *}(, 778)$ & $-0,255^{* *}(, 775)$ & $-0,027(, 973)$ &,$- 025(, 975)$ \\
\hline & (area) \% unemployed & $0,292^{* *}(1,339)$ & $0,178^{* *}(1,195)$ & $0,151^{* *}(1,163)$ &, $133^{* *}(1,142)$ \\
\hline & Residential stability & $0,020(1,020)$ & $0,015(1,015)$ & $0,324^{* *}(1,383)$ &, $325^{* *}(1,384)$ \\
\hline & Gender $($ male $=1)$ & $-0,057(, 945)$ & $-0,048(, 953)$ & $0,063(1,065)$ & ,064 (,1,066) \\
\hline & Elderly (over $65=1$ ) & $0,012(1,012)$ & $0,033(1,034)$ & $0,700^{* *}(2,014)$ &, $701^{* *}(2,016)$ \\
\hline \multirow[t]{12}{*}{ Rental Ownership } & Svenska bostader & & $0,714^{* *}(2,041)$ & & , $107(1,113)$ \\
\hline & Familie bostader & & $0,68^{* *}(1,974)$ & & $-.037(, 963)$ \\
\hline & Stockholmshem & & $0,513^{* *}(1,670)$ & & , 130 (1,138) \\
\hline & Privately owned & & ref & & ref \\
\hline & Constant & $-2,463^{* *}(, 085)$ & $-2,611^{* *}(0,073)$ & $-2,068^{*}(, 126)$ & $-2,068^{* *}(, 126)$ \\
\hline & Chi-square improvement, (df) & & $136,629(3)^{* *}$ & & $5,826(3)$ \\
\hline & -2log likelihood & 8776.621 & 8639.992 & 9499.118 & 9493.293 \\
\hline & Nagelkerke $\mathrm{R}^{2}$ & 0.06 & 0.085 & 0.059 & 0.06 \\
\hline & Model \% correct & 69.7 & 70 & 63.2 & 63,3 \\
\hline & Null \% correct & 69.6 & 69.6 & 62.1 & 62,1 \\
\hline & Improvement from null & 0.1 & 0.4 & 1.1 & 1,2 \\
\hline & $N$ & 7407 & 7407 & 7406 & 7406 \\
\hline
\end{tabular}


suggests that one key determinant of HSP adoption is physical building form. Stockholm municipality's rental and condominium units are located mostly in multifamily buildings three or more stories tall, whereas singlefamily houses stand alone on separate parcels of land. A housing units' siting and relationship to neighboring units appears to determine the residents' choice of HSP, which may correspond to the particular constellation of HSP that can best protect a given dwelling against the risk of burglary.

The study also found that homeowners, condominium associations and rental housing managers may turn to different types of HSP to fortify a residence after experiencing a burglary. This points to a key difference between rental and condominium units in terms of HSP adoption. Condominium owners appear to spend more on increased security (by purchasing a security door) than the manager of a rental property (by installing safety locks) in the wake of a recent burglary.

HSP adoption differences among the tenancy types may be explained by differences in income level. In Sweden, the average disposable income of single-family household dwellers is more than twice that of renters. However, Stockholm's inner city areas (dominated by rental and condominium tenancy types) represent an exception to this statistic: the average household income in these areas are as high or higher than some of the outlying areas containing mainly single family homes. An alternative explanation may point to the range of different actors, including member-owners, renters, building managers, boards of directors, etc. who are involved in decisions to adopt HSP in multifamily settings. Adding support to this idea is the finding that public and privately owned rental units were found to adopt security measures at different rates. This difference may be attributed to any number of attributes of the two types of organizations: differences may exist with regards to policy, financing, responsibility structure and/or the relationship between management and residents.

Interestingly, adoption of HSP was impacted by the socio-economic status of renters and condominium dwellers in addition to homeowners. Logic would suggest that since renters and condominium dwellers do not usually directly purchase their own HSP (rather it is provided by the building managers and owner-tenant associations), their socio-economic status would not affect their degree of protection. However this study found the opposite: whether they were homeowners, tenantowners, or renters, the socio-economic status of survey respondents was a significant predictor of HSP adoption. The causal mechanis at work here is unclear, but it may be hypothesized that the collective socio-economic level of the residents of a building or an area may influence the level of HSP adoption procured by the condominium association or housing company.

One areal measure, area unemployment, was included in the model. This was associated with a decrease in the likelihood of some HSP for villa owners, as expected, but it was linked to an increase of some protection measures for renters and condominium dwellers. The inconsistent performance of this variable suggests that there may be other location factors acting through the variable. Due to the fact that certain rental companies and organizations dominate the market in certain parishes of Stockholm, it may be that rental management policies impact the adoption of HSP (Table 4). Future research should seek further explanations for these unexpected findings with regard to both individual and areal economic status and tenancy, and their relationships to HSP adoption.

As shown in the summary table (Table 5), perception of a crime problem and altruistic fear were most consistently associated with the adoption of HSP. The "+" symbols indicate a significant and positive association with adoption, where as the "-" symbols indicate a significant and negative association.

Table 5 Significant predictors of HSP, by tenancy type

\begin{tabular}{|c|c|c|c|c|c|c|c|c|c|c|c|}
\hline & & \multicolumn{3}{|l|}{ Rent } & \multicolumn{3}{|c|}{ Condo } & \multicolumn{4}{|l|}{ Villa } \\
\hline & & Door & Locks & Dog & Door & Locks & Dog & Locks & Dog & Alarm & Box \\
\hline \multirow[t]{4}{*}{ Safety } & Burglary victim & & + & & - & & & & + & & \\
\hline & Perception of crime & + & + & + & + & + & + & + & & + & + \\
\hline & Altruistic fear & + & + & + & & + & + & + & + & + & + \\
\hline & Fear in the media & + & & & + & & & + & & & - \\
\hline \multirow[t]{4}{*}{ Control } & Financial umbrella & + & + & & + & + & & + & - & + & \\
\hline & Trouble paying bills & - & & & & - & & & & - & - \\
\hline & Unemployment & + & + & & + & & & & & - & - \\
\hline & Residential stability & & + & & & + & & + & + & & + \\
\hline
\end{tabular}

+ indicates positive coefficient, significant at $p<.05$

- indicates negative coefficient, significant at $p<.05$ 


\section{Conclusions}

This study examines the importance of tenancy type, crime and fear of crime on the adoption household safety protection (HSP). Type of tenancy is identified as a fundamental, previously overlooked, correlate of HSP adoption. When tested in a Swedish context, HSP adoption is consistently associated with residents' fear for loved ones and perception of crime in the neighborhood, but only rarely previous victimization. The use of safety locks, security doors, watch dogs, burglar alarms and safe deposit boxes was greater for those who experienced altruistic fear and perceived that crime was a problem in their neighborhood. By contrast, previous victimization was associated with an increased probability of adoption in only a few cases: burglarized renters reported a higher frequency of safety locks, and victimized villa owners more frequently reported having watch dogs. To a certain extent, these findings uphold previous research, but stand in contrast to previous studies (e.g., Lavrakas and Lewis 1980; May et al. 2010) that found an effect of previous victimization on HSP adoption.

The study modeled the adoption of five individual HSP measures in three types of tenancy. Correlates of the HSP were found to vary significantly among the three tenancy types, and between types of HSP. This finding demonstrates that each type of HSP is a unique behavioral response. This finding adds nuance to that of previous studies which collapsed multiple types of HSP into a single concept of protective behavior (e.g., H. Lee et al. 2008; May et al. 2010; Hirschfield et al. 2004).

New insight was also gained by interpreting the survey results with regard to tenancy type. This approach revealed that renters and condominium owners experience similar patterns of HSP, in contrast to single family homeowners, but that differences still exist between rental and condominium tenant-owners, and even among those residing in rental units owned by different types of housing companies. Future research on HSP should focus on better understanding the process of adoption, especially in various types of multi-family dwellings.

There are a number of limitations with regards to this study. Some results suggested that the survey items pertaining to HSP adoption were not uniformly interpreted by the respondents. Systematic bias was identified in response rate across district areas; the study may be improved by weighting responses in order to correct for this. Some socio-demographic and housing factors are varied across Stockholm's district areas. An exploratory spatial data analysis may be recommended to identify any spatial effects. This study did not include data on the insurance purchases of the respondents or the cost of HSP purchases or operation, all potentially important drivers of HSP purchase. Furthermore, the small number of previous victims included in the survey may have affected results related to victimization and HSP adoption; future surveys may adopt a sampling strategy to include a larger number of previous burglary victims. The crime in the media proxy could be improved by including more than one media source and by measuring media exposure at the individual, rather than an aggregated areal level. Perhaps most important is the limitation due to the cross-sectional nature of the data itself. Hence, any interpretation of the study's findings must be carefully limited as direction of causality cannot be determined.

This study found that renters and condominium ownermembers in Stockholm with lower socio-economic status reported lower levels of key safety measures. This may be of interest to planners and practitioners seeking to establish a just and sustainable society. Regional or national standards for HSP measures in multi-family housing may help to provide increased levels of safety for lower SES residents. For researchers, the results of this study are in many ways just a first look at HSP for multi-family dwellers. Future research should further investigate the underlying process of HSP adoption in condominium and rental tenancy situations.

\section{Appendix \\ 'Trygghet i din stadsdel' survey}

(questions used for the study)

During the past 12 months has your home been exposed to
a robbery or theft?
$\quad \square$ No
$\square$ Yes, ...................... times (Indicate how many times during the past 12 months)

\section{Have you heard about crime (for instance burglary, car theft, vandalism or the like) being committed in or near your housing area? \\ There are no crimes committed in or near our housing area \\ No, I have not heard anything \\ $\square$ Yes, I have heard about one crime \\ Yes, I have hear about many crimes}

\section{What type of housing do you live in?}

Rented apartment owned by Svenska bostäder

Rented apartment owned by Familjebostäder

Rented apartment owned by Stockholmshem

Rented apartment, privately owned

Co-operative flat/apartment

Row house, link house or semidetached house

Detached house (villa) 
How long have you lived in your current housing area?

Less than a year

1 - 5 years

More than 5 years

\section{Cross in that which corresponds to how you (and your family) feel}

(You can check more than one alternative)

$\square$ I/we own our own dwelling

$\square$ I/we own our own summer house/cottage

I/we own a car

I/we own caravan/trailer and/or boat

I/we go on vacation trips every or every other year

$\square$ I/we can go to the dentist when we need to and at least once a year

If, because of unforeseen circumstances, I/we should need 14 000 Swedish crowns within a week, is it possible for me/us to raise this?

During the past 12 months it has happened that I/ we have had difficulties in paying for running expenses like rent, food and other bills.

I/we have comprehensive home insurance

$\square$ I/we regularly save money for my/our retirement

Has it happened during the past 12 months that you have been worried that someone close to you may be the victim of a crime?

$\square$ Yes, very often

$\square$ Yes, pretty often

$\square$ Seldom

No, not worried at all

Are you?

Male

Female

\section{What year were you born?}

19.

\section{Do you protect your house/apartment/dwelling in any of the following ways?}

(You can choose more than one alternative)

$\square$ I have not taken any extra measures for protection

Safety locks

Locks on some windows

Wrought iron Safe deposit box

Burglar alarm

Security door

Lock on balcony door

$\square$ Watch dog

$\square$ I ask neighbors/friends to check my dwelling now and again when I/we are away

\section{Competing interests}

The authors declare that they have no competing interests.

\section{Authors' contributions}

BC participated in the study's design, carried out the data analysis, and drafted the manuscript. VC conceived of the study, participated in its' design and reviewed and edited the manuscript. All authors read and approved the final manuscript.

\section{Acknowledgements}

The authors' would like to thank Tom Petersen for his valuable feedback and suggestions, as well as Adriaan Cornelis Uittenbogaard for his help with preparing some of the data used in the study. Thanks also to Niklas Roth and Stockholm stad socialförvaltningen for providing their survey data.

Received: 24 February 2014 Accepted: 19 June 2015

Published online: 20 August 2015

\section{References}

AcaStat (2012). Chi Square Measures of Association. Applied Statistics Handbook. Available at: http://www.acastat.com/Statbook/chisqassoc.htm [Accessed February 25, 2012].

Agresti, A (2007). An Intoduction to Categorical Data Analysis. John Wiley \& Sons: Hoboken, New Jersey.

Averdijk, M. (2010). Reciprocal effects of victimization and routine activities. Journal of Quantitative Criminology, 27(2), 125-149. doi:10.1007/s10940-010-9106-6.

Clarke, R. V. (1995). Situational crime prevention. In M. Tonry \& D. Farrington (Eds.), Building a safer society: Strategic approaches to crime prevention (pp. 91-150). Chicago: University of Chicago Press.

Cohen, L, \& Felson, M. (1979). Social change and crime rate trends: a routine activity approach. American Sociological Review, 44(4), 588-608.

Demker, M, Towns, A, Duus-Otterström, G, \& Sebring, J. (2008). Fear and punishment in Sweden. Punishment \& Society, 10(3), 319-332. doi:10.1177/ 1462474508090228.

Eurostat (2012). Crime Trends in Detail - Statistics Explained. European Commission. http://epp.eurostat.ec.europa.eu/statistics_explained/index.php/ Crime_trends_in_detail.

Ferguson, KM, \& Mindel, CH. (2007). Modeling fear of crime in Dallas neighborhoods. Crime \& Delinquency, 53(2), 322-349. doi:10.1177/0011128705285039.

Gabriel, U, \& Greve, W. (2003). The psychology of fear of crime: conceptual and methodological perspectives. British Journal of Criminology, 43(3), 600.

Gelders, D, Peeraer, H, \& Goossens, J. (2007). Public communication about home burglary prevention in Belgium: strengths and weaknesses tested by content analysis and focus group interviews. Policing: An International Journal of Police Strategies \& Management, 30(4), 567-586. doi:10.1108/13639510710833875.

Goold, B, Loader, I, \& Thumala, A. (2010). Consuming security?: Tools for a sociology of security consumption. Theoretical Criminology, 14(1), 3-30. doi:10.1177/1362480609354533.

Greenberg, S. (1987). Why people take precautions against crime: a review of the literature on individual and collective responses to crime. In ND Weinstein (Ed.), Taking Care: Understanding and Encouraging Self-protective Behavior (pp. 231-253). New York: Cambridge University Press.

Hirschfield, A, Bowers, KJ, \& Johnson, SD. (2004). Inter-relationships between perceptions of safety, anti-social behaviour and security measures in disadvantaged areas. Security Journal, 17(1), 9-19. doi:10.1057/ palgrave.sj.8340158.

Lauer, J. (2005). Driven to extremes: fear of crime and the rise of the sport utility vehicle in the United States. Crime, Media, Culture, 1(2), 149-168. doi:10.1177/ 1741659005054024.

Lavrakas, PJ, \& Lewis, DA. (1980). The conceptualization and measurement of citizens' crime prevention behaviors. Journal of Research in Crime and Delinquency, 17(2), 254-272. doi:10.1177/002242788001700208.

Lee, S (2010a). Installation Trends and Characteristics of Residential Burglar Alarms. Journal of Applied Security Research, 5 (2), 176-207. doi:10.1080/ 19361611003601058.

Lee, S (2010b). Spatial Analyses of Installation Patterns and Characteristics of Residential Burglar Alarms. Journal of Applied Security Research, 6 (1), 82-109. doi:10.1080/19361610.2011.529414

Lee, H, Lee, A, Clinton, M, Zhang, G, \& Fraser, M. (2008). Protecting older people from burglary: prevalence of security devices in the homes of older adults in Perth, Western Australia. Journal of Housing for the Elderly, 22(4), 335-347. 
Loader, I. (1999). Consumer culture and the commodification of policing and security. Sociology, 33(2), 373-392.

Maguire, M, \& Bennet, T. (1982). Burglary in a dwelling: the offence, the offender and the victim. London: Heinemann.

May, DC, Rader, NE, \& Goodrum, S. (2010). A gendered assessment of the 'threat of Victimization': examining gender differences in fear of crime, perceived risk, avoidance, and defensive behaviors. Criminal Justice Review, 35(2), 159-182. doi:10.1177/0734016809349166.

Mitt i (2014). Annonswebb. http://annons.mitti.se/rackvidd/. Accessed 22 November 2014.

Nilsson, A, \& Estrada, F. (2006). The inequality of victimization trends in exposure to crime among rich and poor. European Journal of Criminology, 3(4), 387-412. doi:10.1177/1477370806067910.

Rodgers, D. (2004). 'Disembedding' the City: crime, insecurity and spatial organization in Managua, Nicaragua. Environment and Urbanization 16(2), 113-124. doi:10.1177/095624780401600202.

Roth, N. \& Sandahl, J., (2008). Trygg i Stockholm? En stadsövergripande trygghetsmätning, Stockholm: Socialtjänstförvaltningen.

Rountree, PW, \& Land, KC. (1996). Perceived risk versus fear of crime: empirical evidence of conceptually distinct reactions in survey data. Social Forces, 74(4), 1353-1376. doi:10.2307/2580354.

Smith, SJ, \& Pain, R. (2009). Critical Geopolitics and Everyday Fears. In M Lee \& S Farrall (Eds.), Fear of Crime: Critical Voices in an Age of Anxiety (pp. 45-58). New York/ Abingdon: Routledge-Cavendish.

Svenska Dagbladet (2013). Sportlovet inbrottstjuvens högtid. http://www.svd.se/ sportlovet-inbrottstjuvens-hogtid. Accessed 28 Aug 2013.

The Swedish National Council for Crime Prevention (Brå) (2008).The Swedish Crime Survey 2008. Accessed at: http://www.bra.se/download/ 18.cba82f7130f475a2f1800023143/1371914733395/ 2009_2_swedish_crime_survey_2008.pdf.

Tilley, N, Tseloni, A, \& Farrell, G. (2011). Income disparities of burglary risk. British Journal of Criminology, 51(2), 296-313. doi:10.1093/bjc/azr010

Töyrä, A (2008). Brottsutvecklingen i Sverige Fram till År 2007 Kapitel: Bostadsinbrott. 23. Bra.

USKAB (2010). Statistik Om Stockholm, Statistisk Årsbok För Stockholm. http:// www.statistikomstockholm.se/attachments/article/38/arsbok_2010.pdf. Accessed 24 Feb 2012.

Van Dijk, J, Manchin, R, van Kesteren, J, Nevala, S, Hideg, G (2005). “The Burden of Crime in the EU." EU ICS. http://www.marchesicure.it/documenti/ EUICS_full_report.doc. Accessed 24 June 2013.

Warr, M. (1984). Fear and victimization: Why are women and the elderly more afraid? Social Science Quarterly, 65, 681-702.

Warr, M, \& Ellison, CG. (2000). Rethinking social reactions to crime: personal and altruistic fear in family households. American Journal of Sociology, 106(3), 551-578. doi:10.1086/318964.

Zedner, L. (2007). Pre-crime and post-criminology? Theoretical Criminology, $11(2), 261-281$

\section{Submit your manuscript to a SpringerOpen ${ }^{\circ}$ journal and benefit from:}

- Convenient online submission

- Rigorous peer review

- Immediate publication on acceptance

- Open access: articles freely available online

- High visibility within the field

- Retaining the copyright to your article

Submit your next manuscript at $\gg$ springeropen.com 